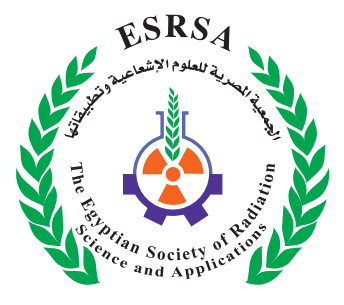

J. Nucl. Tech. Appl. Sci., Vol. 7, PP. 133 : 150 (2019)

\title{
Effect of Silver Nanoparticles on distribution of Certain Trace Elements in Various Organs of Normal and Gamma Irradiated Rats
}

Amin, Y.M. ${ }^{1}$; Hawas, A.M. ${ }^{1}$; Elsayed, M.E. ${ }^{2}$; Kenawy, S.A. ${ }^{2}$; Hassan, S.H.M. ${ }^{1}$; El-Batal A.I. ${ }^{1}$

Received: $16 / 01 / 2019$

Accepted: 01/04/2019

E.mail: asrar_hawas@yahoo.com

\section{KEYWORDS}

AgNPs, $\gamma$-radiation, iron, zinc, calcium.

\section{ABSTRACT}

The present study was performed to evaluate the effect of 28 days subchronic oral administration of AgNPs in normal and irradiated (4 Gy) rats on the distribution of certain trace elements (silver $(\mathrm{Ag})$, zinc $(\mathrm{Zn})$, copper $(\mathrm{Cu})$, iron $(\mathrm{Fe})$, calcium $(\mathrm{Ca})$, magnesium $(\mathrm{Mg})$ and manganese $(\mathrm{Mn})$ contents in various organs tissues including liver, kidney, lung and testes. AgNPs were orally administered daily for 28 days continuously and the vehicle as well in the vehicle group. The study was performed to investigate the effect of AgNPs on trace elements in different organs and as compared with irradiated treated AgNPs group. Results of the present study demonstrated that subchronic oral administration of AgNPs $(26.878 \mathrm{mg} / \mathrm{kg} \mathrm{b}$. wt.) induced changed in the concentration of the estimated essential elements in the various tissues examined of normal rats. The recorded changes in the tested trace elements pointed to ( $\mathrm{Zn}$ ), $(\mathrm{Fe})$ and $(\mathrm{Ca})$ content in liver, kidney, lung and testes tissues. Radiation exposure (4Gy) of rats produced marked alterations in the distribution of tested trace elements in all tissues investigated of irradiated rats, concerned with $(\mathrm{Zn}),(\mathrm{Cu}),(\mathrm{Fe}),(\mathrm{Ca}),(\mathrm{Mg})$ and $(\mathrm{Mn})$ in liver, kidney, lung and testes tissues. Combined exposure to $\gamma$-radiation (4Gy) and AgNPs $(42.599 \mathrm{mg} / \mathrm{kg} \mathrm{b}$. wt.) treatment showed marked variation in trace elements content of $(\mathrm{Zn}),(\mathrm{Cu}),(\mathrm{Fe}),(\mathrm{Ca}),(\mathrm{Mg})$ and $(\mathrm{Mn})$ of the selected tissues examined. Such variations were more or less pronounced than the individual effects of either AgNPs treatments or $\gamma$-radiation exposure. The detected variation in the concentrations of the estimated trace

1. 1. National Center for Radiation Research and Technology, Atomic Energy Authority, 11787, Egypt

2. 2. Department of Pharmacology \& Toxicology, Faculty of Pharmacy, Cairo University, 11562, Egypt 
elements of various tested organs might be attributed to the selective responsiveness of each tissue to the combined effect of both AgNPs treatment and $\gamma$-radiation. In conclusion, AgNPs administration after $\gamma$-radiation has considerate effect on the levels of metals in liver and lung tissues which give attention that these organs more sensitive to AgNPs.

\section{INTRODUCTION}

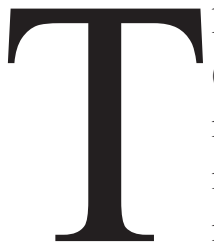

he novel characters of nanoparticles (NPs) have been introduced in a wide range of applications in medicine, cosmetics, renewable energies, environmental remediation and biomedical apparatus (De et al., 2008; Ghosh Chaudhuri and Paria, 2012). Silver nanoparticles (AgNPs) have unique physical, chemical and biological properties compared to their macro-scaled counterparts (Sharma et al., 2009). Thus, AgNPs were used as antimicrobial coatings in medical devices as catheters to reduce infections at hospitals (Roe et al., 2008). AgNPs were also used in therapeutics, especially for treating burn wounds which it can suppresses both local and systemic inflammation in wound healing model. Moreover, AgNPs have been demonstrated as an effective biocide against broad-spectrum bacteria including many highly pathogenic bacterial strains as gram-negative and gram-positive bacteria (Marambio-Jones and Hoek 2010, Morones et al., 2005). Also AgNPs have been reported to have inhibitory effects on H1N1 influenza A virus, HIV1 virus and on hepatitis B virus (Lu et al., 2008). Consequently, the increasing usage of AgNPs in a wide range of medical applications has need for assessment its toxic effects on health (Christensen $\boldsymbol{e t}$ al., 2010). AgNPs ability to penetrate through biological barriers (Van der Zande et al., 2012) lead to accumulation and release high concentrations of the univalent silver ions in the cells under the action of oxidizers (Lubick, 2008, Xiu et al., 2012), which is called "the Trojan horse effect" (Choi et al., 2008). On the other hand, Ag salts form can interact with the protein thiol groups that are responsible on transport and metabolism of trace elements, which can cause their imbalance and lead to the development of toxic effects (Benetti et al., 2014). However, there is no sufficient information in the literature about the influence of AgNPs introduced through the gastrointestinal tract on the homeostasis of the main essential and toxic trace elements (Gmoshinski et al., 2016).

Essential trace elements are minerals found in the organism nutriment which they cannot produce by itself. These elements play a vital role in the body to perform the functions properly. These elements should present in the body in specific amounts to be available for reacting with other elements as well as to participate in various chemical reactions in the cell. Deficiency of the essential elements can lead to problems. The action of all these mineral ions naturally restores optimum performance to the cell (Shazia et al., 2012). Essential trace elements comprise $\mathrm{Fe}, \mathrm{Cu}, \mathrm{Zn}, \mathrm{Mg}, \mathrm{Ca}$ and $\mathrm{Mn}$. While the non-essential trace elements are not usually found in the human organism and have no natural physiological role but they do have pharmacological properties as aluminium, silver, bismuth, lithium and gold.

Radiation is known to produce noticeable damage to living tissues. Free radicals are generated when biological systems are exposed to ionizing radiation. The generation of radiation-induced free radicals is considered to be the primary cause of the radiation induced damage to biological systems. The deleterious effects of ionizing radiation could be related to free radicals propagation. Radiation injury to living biological tissues is usually characterizes by changes in membranes permeability which accompanied with corresponding alteration in the essential trace elements contents of $\mathrm{Fe}, \mathrm{Cu}, \mathrm{Zn}$ and $\mathrm{Mg}$ in various organs including liver, spleen, kidney, heart and lung (Hassan et al., 2005).

The effect of silver nanoparticles (AgNPs) on the vital role of trace elements in the body to perform 
its function properly remains a controversial point of research concerning the risk/benefit ratio of their use alone and in combination with a gamma irradiation. Given that the AgNPs and $\gamma$-radiation have medical applications on the organism, the present study conducted to evaluate the alone or combined effect of them on the distribution of essential trace elements, $\mathrm{Zn}, \mathrm{Cu}, \mathrm{Fe}, \mathrm{Ca}, \mathrm{Mg}, \mathrm{Mn}$ as well as $\mathrm{Ag}$ in various organs including: liver, kidney, lung and testes in response to AgNPs treatment in normal and irradiated rats.

\section{MATERIAL AND METHODS}

\section{Material}

Animals: Wistar male albino rats weighing 150-180 g were used. Animals were obtained from National Research Center, Cairo, Egypt. Rats were housed in plastic cages and were maintained under conventional laboratory conditions throughout the study. They were fed standard pellet chow (El-Nasr chemical Co., Abu Zaabal, Cairo and Egypt) and water ad libitum. The animal treatment protocol has been approved by Research Ethics committee (REC) (S.N.: 8A/17) of the National Center for Radiation Research and Technology (NCRRT), Cairo, Egypt.

\section{Drugs and chemicals:}

AgNPs were synthesized by chemical method at the national center for radiation research and technology (NCRRT). AgNPs were administered orally for 28 days. The selected doses of AgNPs were carried out according to the preliminary experimental trials. According to the previous work (Amin et al., 2015) $\mathrm{LD}_{50}$ of AgNPs in normal mice was 268.787 $\mathrm{mg} / \mathrm{kg}$ b. wt. however $\mathrm{LD}_{50}$ of AgNPs was 429.55 $\mathrm{mg} / \mathrm{kg}$ in irradiated rats. The chosen doses of 26.878 $\mathrm{mg} / \mathrm{kg}$ and $42.599 \mathrm{mg} / \mathrm{kg}$ b. wt. corresponds to $1 / 10$ $\mathrm{LD}_{50}$ in normal and irradiated animals respectively (Amin et al., 2015). Polyvinylepyrrolidone was purchased from Sigma-Aldrich chemical co. (U.S.A), to be orally administered as the vehicle control group in equivalent volume to the AgNPs and irradiated treated AgNPs groups.

\section{Preparation of silver nanoparticles:}

AgNPs were synthesized at Drug Radiation Research Dep. labs, at the national center for radiation research and technology (NCRRT) according to a modified method of Mao et al., (2012); El-Batal et al. (2013a) and El-Batal et al. (2013b).

\section{Irradiation}

Rat's whole body gamma irradiation was performed at the national center for radiation research and technology (NCRRT), Cairo, Egypt, using an AECL Gamma cell-40 biological indicator. Animals were irradiated at an acute single dose level of $4 \mathrm{~Gy}$ delivered at a dose rate of $0.758 \mathrm{rad} / \mathrm{sec}$.

\section{Experimental design:}

Rats were classified into 5 groups, each consists of 8 rats. The examined groups were: normal control received saline, vehicle control group received polyvinylpyrrolidone (PVP), silver nanoparticles (AgNPs) normal group in which rats were received $26.878 \mathrm{mg} / \mathrm{kg}$ body wt., irradiated group in which rats exposed to 4 Gy gamma radiations, irradiated treated group where rats were exposed to 4 Gy gamma irradiation followed by oral administration of $42.599 \mathrm{mg} / \mathrm{kg}$ body wt. AgNPs. Saline, PVP, AgNPs were administered orally for 28 consecutive days (Van der Zande et al., 2012 and Loeschner $\boldsymbol{e t}$ al., 2011) and were fasted overnight. On the day 29 , all groups of the rats were anaesthetized by diethyl ether. Rats from the previously mentioned groups were sacrificed, and the selected organs (liver, kidney, lung and testes) were isolated.

\section{Sample preparation:}

Tissue samples (liver, kidney, lung and testes) were washed thoroughly by deionized water. Approximately $0.5 \mathrm{~g}$ of tissues were put in special vessels with $4 \mathrm{ml}$ concentrated pure nitric acid (65\%) 
and $1 \mathrm{ml}$ hydrogen peroxide (IAEA, 1980 and Hawas, 2013) for the digestion process using Milestone MLS 1200 Mega, High Performance Microwave Digestor Unit. The sample was converted to soluble matter then diluted with deionized water to appropriate concentration level. Trace elements were detected quantitatively using standard curve method (Kingston and Jassie, 1988).

\section{Trace elements assessment:}

Assessments of trace element levels in the various tissues of rats were carried out using Thermo Scientific ICE 3000 Series Atomic Absorption Spectrometry, equipped with deuterium background correction. Estimation of the tested trace elements $(\mathrm{Ag}$, $\mathrm{Zn}, \mathrm{Cu}, \mathrm{Fe}, \mathrm{Ca}, \mathrm{Mg}$ and $\mathrm{Mn}$,) of the selected tissues under investigations was carried out using hollow cathode lambs for each element. Each element concentration was calculated via applying the method of calibration curve using standard stock solutions $1000 \mathrm{microgram} / \mathrm{ml}$ for each studied element.

The element concentration in the original sample could be determined from the following equation:

$\mathrm{C} 2$ microgram/gram $=\mathrm{C} 1$ microgram $\mathrm{X} \mathrm{D} /$ sample weight

Where:

$\mathrm{C} 1=$ metal concentration in solution

$\mathrm{C} 2=$ metal concentration in sample

$\mathrm{D}=$ dilution factor

The concentrations of the different studied elements were calculated through solar data station.

\section{Statistical analysis:}

The values of the measured parameters were presented as mean $\pm \mathrm{SE}$. Comparisons between different treatments were carried out using one way analysis of Variance (ANOVA) followed by TukeyKramer as post ANOVA multiple comparisons test. Differences were considered statistically significant at $\mathrm{p}<0.05$.

\section{RESULTS}

\section{Characteriztion of silver nanoparticles}

UV-VIS spectral analysis: Preliminary characterization of the silver nanoparticles was carried out using UV-visible spectroscopy (JASCOJapanmodel V- 560) at a resolution of $1 \mathrm{~nm}$. Noble metals, especially gold $(\mathrm{Au})$ and silver nanoparticles exhibit unique and tunable optical properties on account of their surface Plasmon resonance (SPR), dependent on shape, size and size distribution of the nanoparticles (Tripathy et al., 2010). The decrease of silver ions was monitored by measuring the UV-visible spectra of the solutions from 300 to $800 \mathrm{~nm}$. Fig.1.

Dynamic light scattering (DLS): Average particle size and size distribution were determined by the dynamic light scattering (DLS). (Loeschner et al., 2011). technique (PSS-NICOMP $380-Z L S$, USA) to both in situ and ex situ irradiated samples. Before measurements, the samples were diluted 10times with deionized water. $250 \mu$ l of suspension were transferred to a disposable low volume cuvette. After equilibration to a temperature of $25^{\circ} \mathrm{C}$ for $2 \mathrm{~min}$, five measurements were performed using 12 runs of $10 \mathrm{~s}$ each. Fig.2.

\section{Transmission Electron Microscopy (TEM)} The particle size and shape were observed by TEM nanoparticles (Tripathy et al., 2010) (JEOL electron microscope JEM-100 CX) operating at $80 \mathrm{kV}$ accelerating voltage. The prepared Ag-NPS formed by in situ and ex situ radiation was diluted 10 times with deionized water. A drop of the suspension was dripped into coated copper grid and allowed to dry at room temperature. Fig.3.

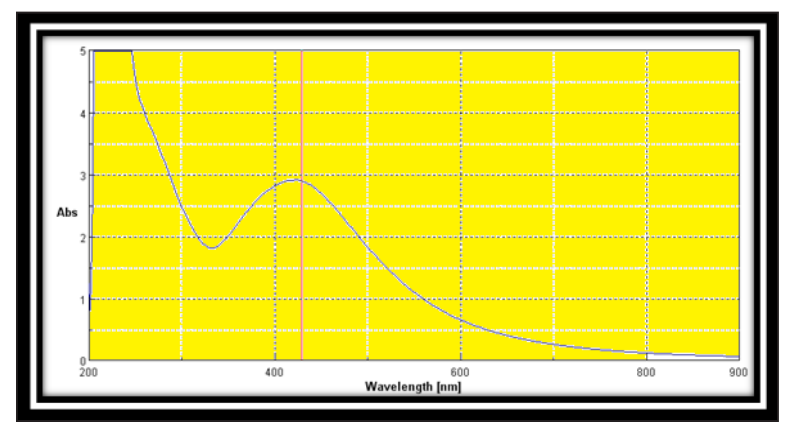

Fig. (1): UV-VIS spectral analysis of AgNPs. 


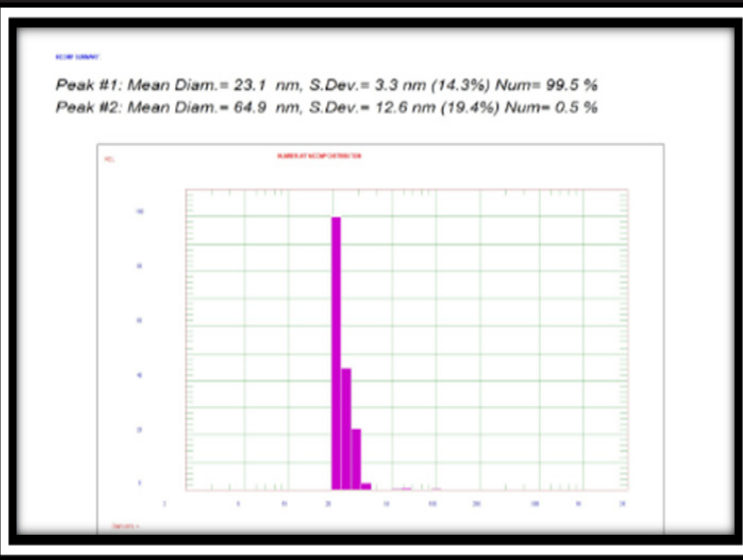

Fig. (2): Dynamic light scattering (DLS) of AgNPs showing the particle size diameter of AgNPs mean value is $23.1 \pm 3.3$ nm.

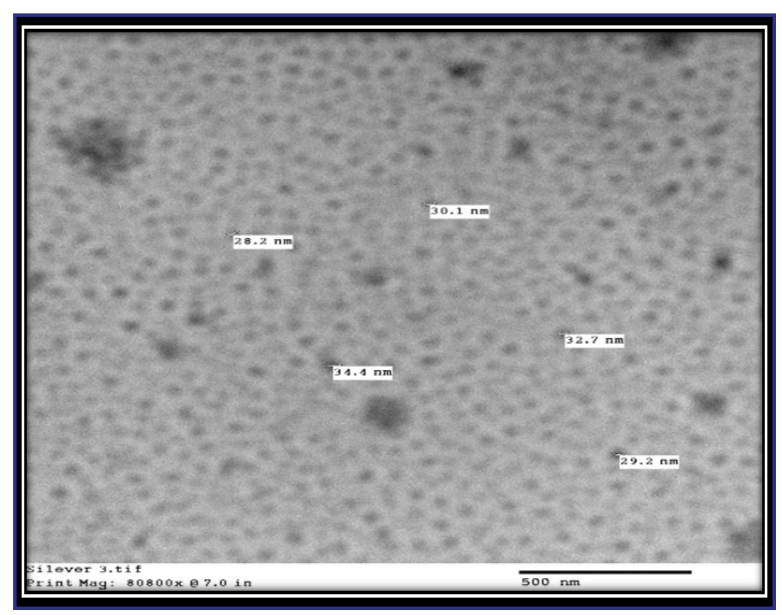

Fig. (3): Transmission Electron Microscopy (TEM) examination of AgNPs showed spherical shape of silver nanoparticles and good particle dispersion with average size at $30.92 \pm 2.56 \mathrm{~nm}$.

\section{Silver (Ag) content in various tissues of normal and irradiated (4Gy) rats treated with AgNPs:}

It has been found that concentrations of $\mathrm{Ag}$ in liver, kidney, lung and testes tissues in the vehicle control, normal control and irradiated groups were below the detection limit. Accumulation of $\mathrm{Ag}$ was observed in liver, kidney and lung tissues due to AgNPs $(26.878 \mathrm{mg} / \mathrm{kg})$ administration but irradiated treated group with AgNPs (42.599 mg/kg) exhibited significant increase of Ag in kidney and testes tissues compared with AgNPs group (Fig.4).

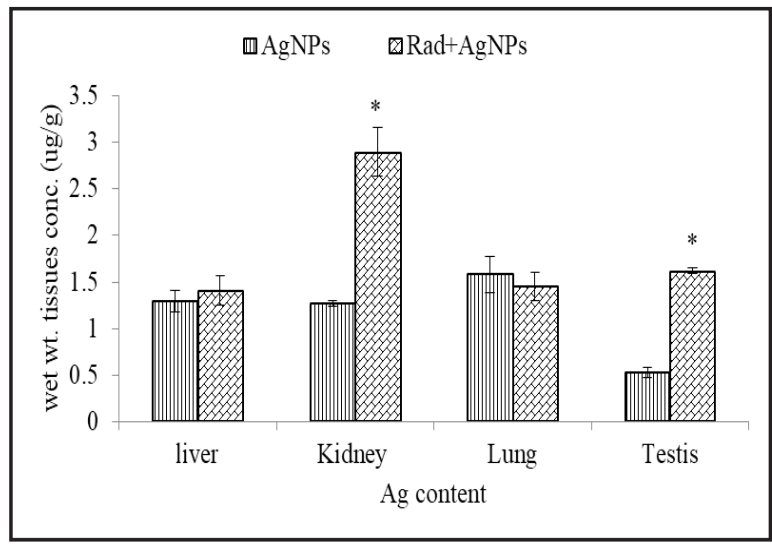

Fig. (4): Effect of AgNPs administration (successive equal doses for 28 days) to normal and irradiated rats on silver contents of liver, kidney, lung and testis.

- $n=8$ rats per group. Data was expressed as mean \pm SE.

- *Significantly different from silver nanoparticles value at $\mathrm{P}<0.05$.

\section{Zinc (Zn) content in various tissues of normal and} irradiated (4Gy) rats treated with AgNPs:

Treatment of normal rats with AgNPs (26.878 $\mathrm{mg} / \mathrm{kg}$ ), showed significant increasing in lung $\mathrm{Zn}$ content as compared to both vehicle and normal control. They showed significant decrease in testes $\mathrm{Zn}$ content as compared to both vehicle and normal control. Irradiation treatment (4Gy) significantly increased $\mathrm{Zn}$ content in liver, lung and testes as compared to vehicle as well as normal controls. Kidney content of $\mathrm{Zn}$ level showed significant increase as compared to vehicle control only. Combined treatment with irradiation (4Gy) and AgNPs (42.599 mg/ $\mathrm{kg}$ ) significantly increased $\mathrm{Zn}$ content in liver, kidney and testes as compared to vehicle control. AgNPs and irradiation have synergistic effect on liver, kidney. AgNPs attenuate the effect of Irradiation on testes while irradiation antagonized the AgNPs effect on Zn lung content. (Fig.5 A, B, C\&D). 

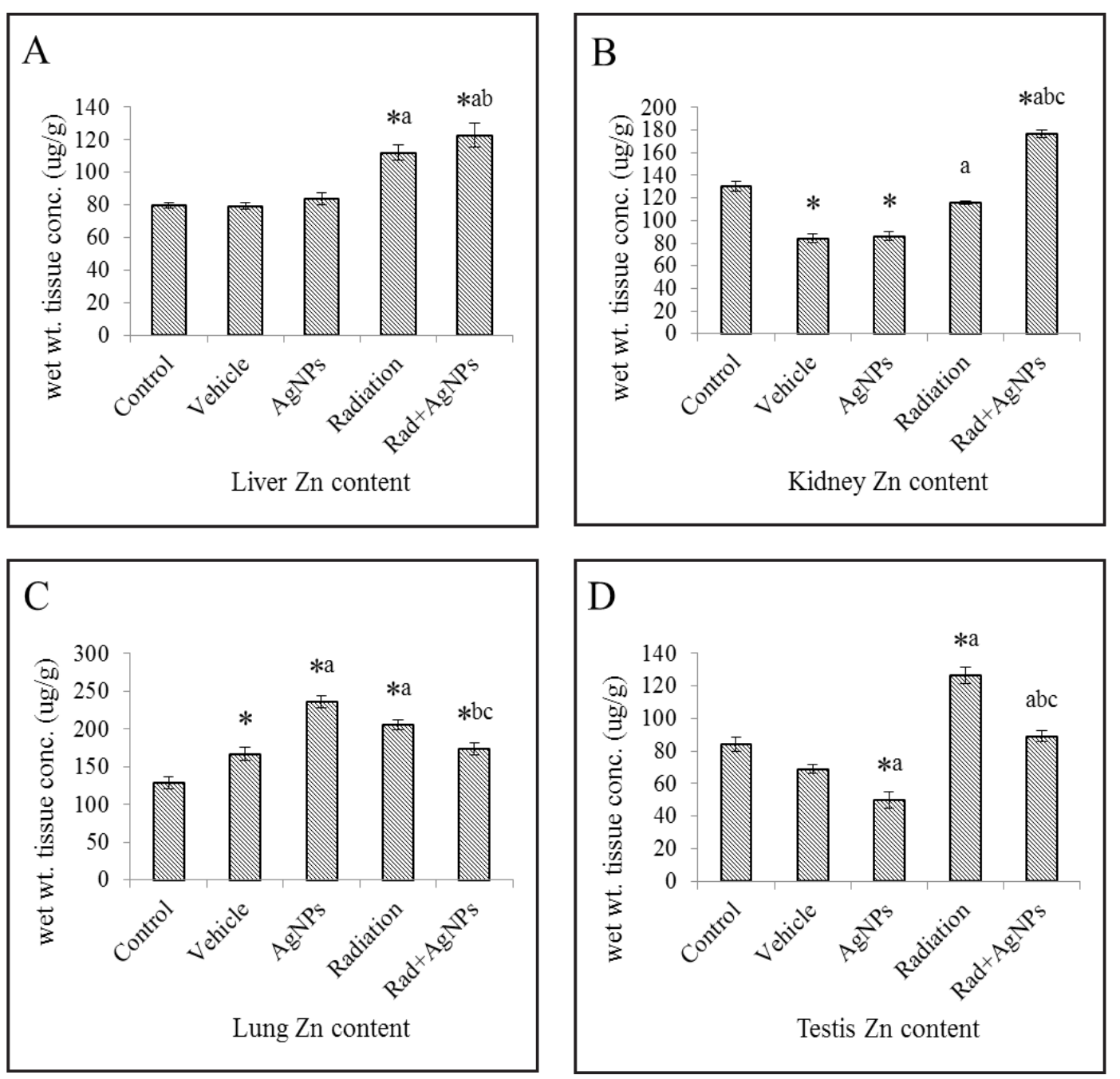

Fig. (5): shows subchronic effect of oral administration of AgNPs for 28 days in normal and irradiated (4Gy) rats on zinc $(\mathrm{Zn})$ contents in liver (A), kidney (B), lung (C) and testis (D) tissues.

- $\mathrm{n}=8$ rats per group. Data was expressed as mean \pm SE. $\mathrm{P}<0.05$.

- * Significantly different from the normal control value.

- a Significantly different from the vehicle control value.

- b Significantly different from silver nanoparticles value.

- c Significantly different from the irradiated control value.

Copper (Cu) content in various tissues of normal and irradiated (4Gy) rats treated with AgNPs:

AgNPs $(26.878 \mathrm{mg} / \mathrm{kg}$ ) administration to normal rats showed significant decrease of $\mathrm{Cu}$ content in lung tissue as compared to vehicle control. Irradiation (4Gy) significantly decreased lung $\mathrm{Cu}$ content as compared to vehicle control. Testes $\mathrm{Cu}$ content of the irradiated (4Gy) group showed significant increase as compared to vehicle and normal controls. Treatment with AgNPs decreased $\mathrm{Cu}$ content in lung as com- pared to vehicle control. Irradiation (4 Gy) of animals decreased $\mathrm{Cu}$ content in lung and increases its content in testes compared to vehicle control. Combined treatments of irradiation (4Gy) and silver nanoparticles $(42.599 \mathrm{mg} / \mathrm{kg}$ ) significantly increased $\mathrm{Cu}$ content in liver tissue however, lung tissue showed significant decrease as compared to vehicle control. AgNPs and irradiation have synergestic effect on liver and lung tissue. AgNPs attenuated the effect of irradiation on testes cu content. (Fig.6 A, B, C\&D). 

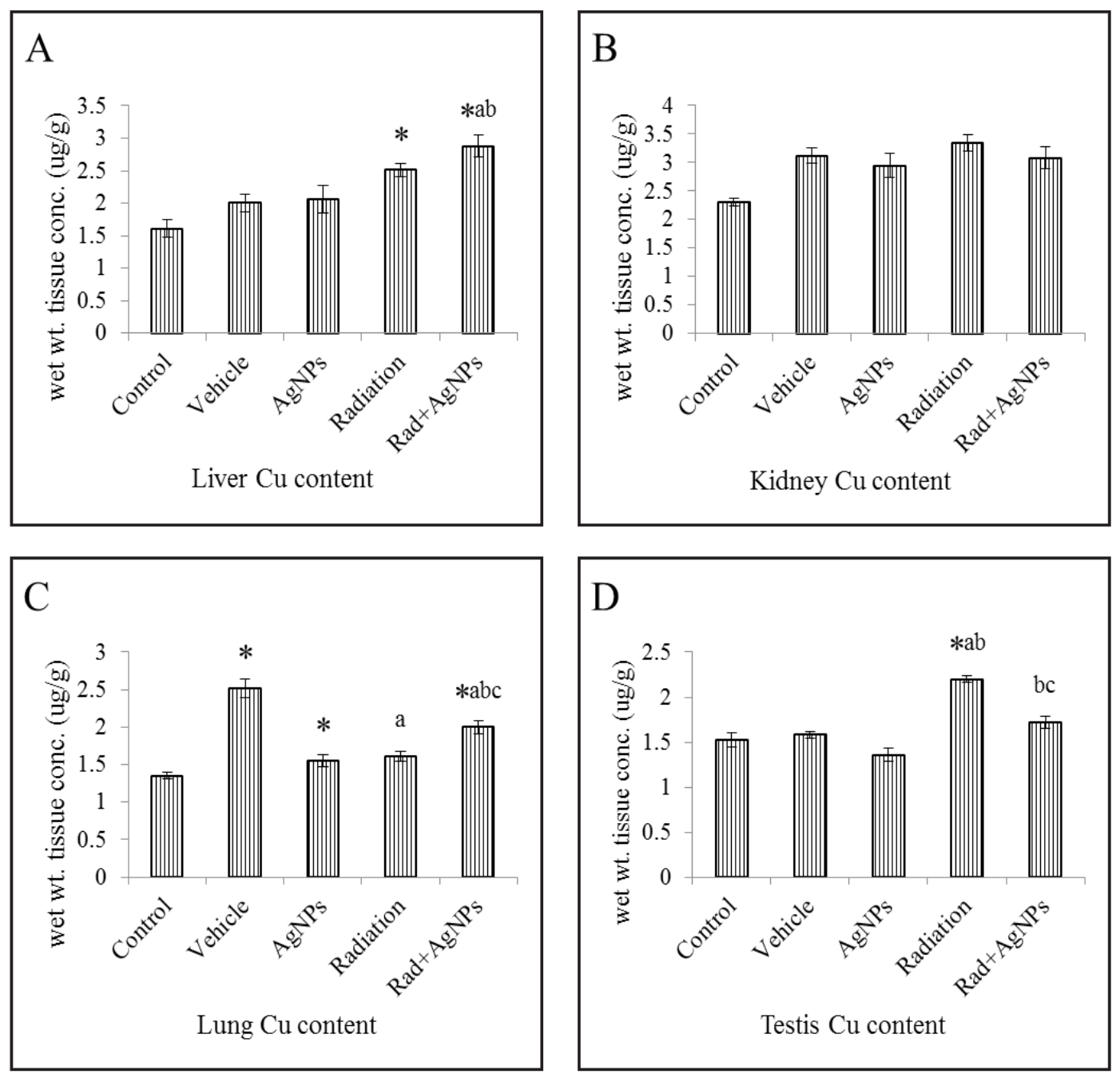

Fig. (6): shows subchronic effect of oral administration of AgNPs for 28 days in normal and irradiated (4Gy) rats on cupper $(\mathrm{Cu})$ contents in liver $(\mathrm{A})$, kidney $(\mathrm{B})$, lung $(\mathrm{C})$ and testis $(\mathrm{D})$ tissues.

- $\mathrm{n}=8$ rats per group. Data was expressed as mean $\pm \mathrm{SE}$. $\mathrm{P}<0.05$.

- *Significantly different from the normal control value.

- a Significantly different from the vehicle control value.

- b Significantly different from silver nanoparticles value.

- c Significantly different from the irradiated control value.

Iron (Fe) content in various tissues of normal and irradiated (4Gy) rats treated with AgNPs:

Treatment with AgNPs $(26.878 \mathrm{mg} / \mathrm{kg})$ showed significant increase of Fe content in liver, kidney and lung tissues as compared to vehicle control as well as, a significant increase in liver and lung tissues as compared to normal control. Irradiation (4Gy) significantly increase liver, lung, kidney and testes Fe contents as compared to vehicle control and signifi-

cantly increased $\mathrm{Fe}$ content in liver, lung and testes as compared to normal control. Combination of irradiation (4Gy) and silver nanoparticles (42.599 mg/kg) treatments significantly increased Fe contents in liver and testes as compared to both vehicle control and normal control, AgNPs antagonized irradiation effect on kidney and lung. AgNPs attenuated the effect of irradiation on testes Fe content. Combined treatment with AgNPs and irradiation showed a synergistic effect on liver Fe content. (Fig.7 A, B, C\&D). 

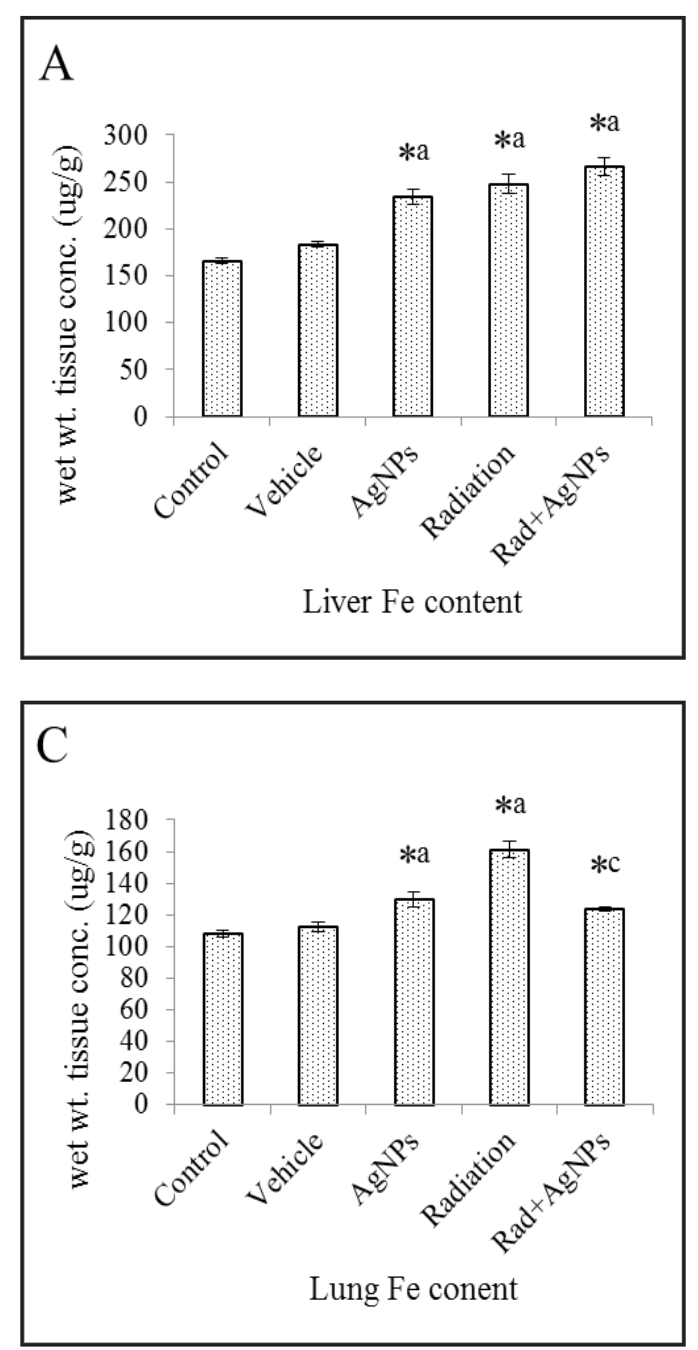

B

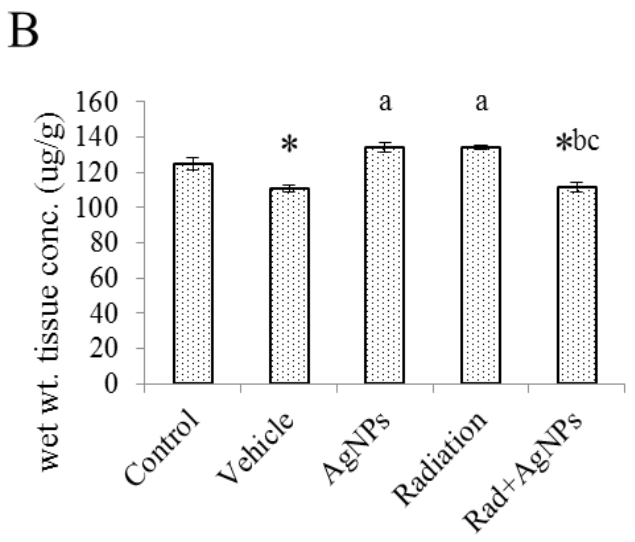

Kidney Fe content

\section{$\mathrm{D}$}

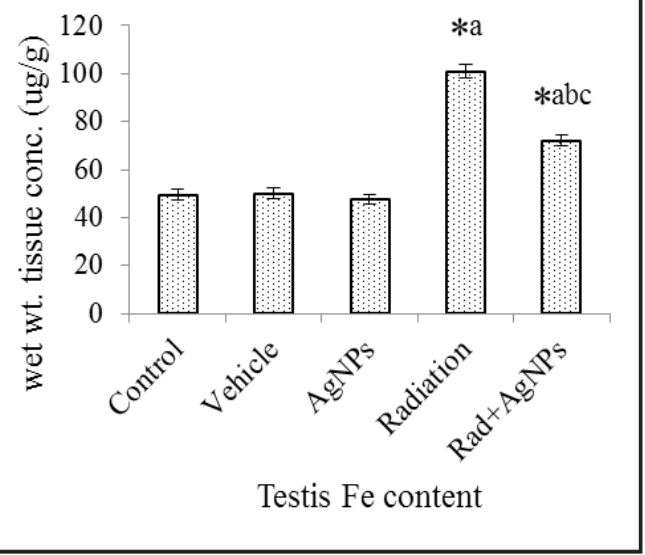

Fig. (7): shows subchronic effect of oral administration of AgNPs for 28 days in normal and irradiated (4Gy) rats on iron (Fe) contents in liver (A), kidney (B), lung (C) and testis (D) tissues.

- $\mathrm{n}=8$ rats per group. Data was expressed as mean $\pm \mathrm{SE}$. $\mathrm{P}<0.05$.

- *Significantly different from the normal control value.

- a Significantly different from the vehicle control value.

- b Significantly different from silver nanoparticles value.

- c Significantly different from the irradiated control value.

\section{Calcium (Ca) contents in various tissues of normal and irradiated (4Gy) rats treated with AgNPs:}

Treatment with AgNPs $(26.878 \mathrm{mg} / \mathrm{kg}$ ) showed a significant decrease in $\mathrm{Ca}$ contents in liver and testes as compared to both vehicle and normal controls. AgNPs showed decrease in lung $\mathrm{Ca}$ content as compared to normal control value accompanied by a significant increase in $\mathrm{Ca}$ content in kidney as compared to normal control. Irradiation (4Gy) of rats significantly decreased liver $\mathrm{Ca}$ content as compared to vehicle control, while lung $\mathrm{Ca}$ content showed significant decrease as compared to normal control. Kidney Ca content of irradiated (4Gy) group showed a significant increase as compared to normal control. Combined treatment with irradiation (4Gy) and silver nanoparticles $(42.599 \mathrm{mg} / \mathrm{kg}$ ) significantly increased Ca content in kidney tissue, while Ca level in lung showed a significant decrease as compared 
to normal control. Irradiation (4Gy) antagonized the effect of AgNPs on liver. AgNPs potentiated the effects of both irradiation on lung $\mathrm{Ca}$ and the effect on
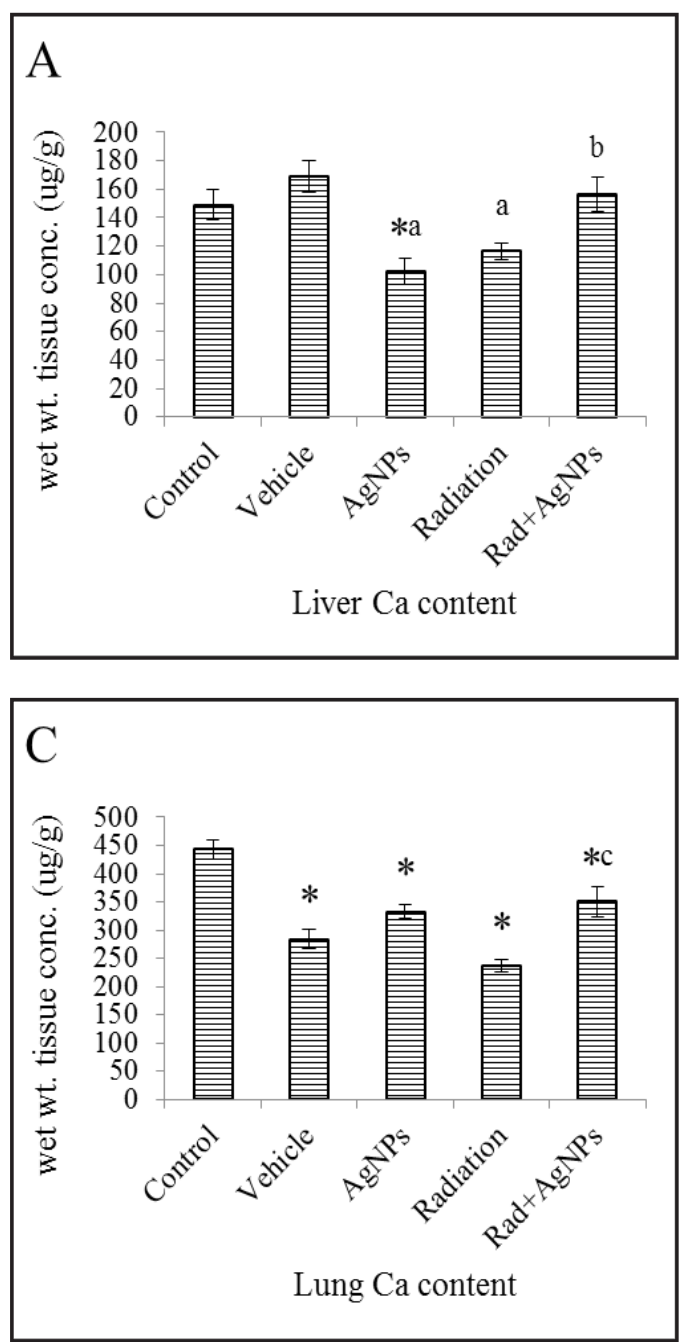

kidney as compared to normal control. (Fig.8 A, B, C\&D).
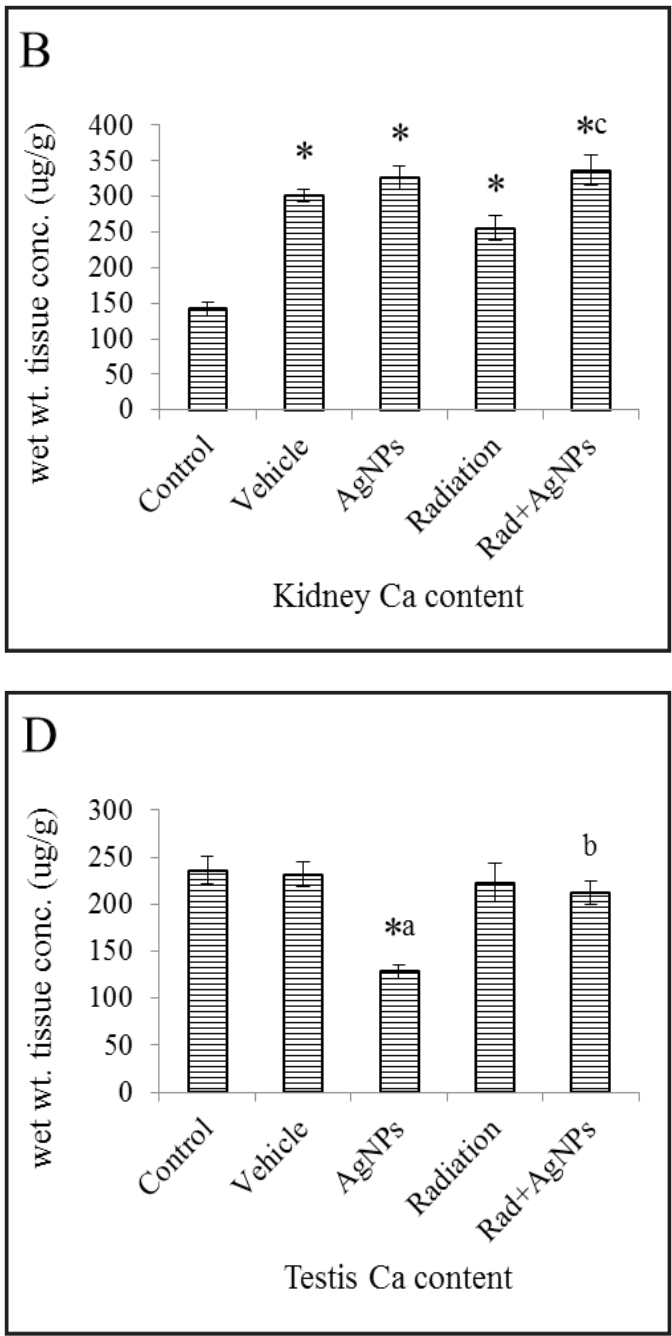

Fig. (8): shows subchronic effect of oral administration of AgNPs for 28 days in normal and irradiated (4Gy) rats on calcium (Ca) contents in liver (A), kidney (B), lung (C) and testis (D) tissues.

- $\mathrm{n}=8$ rats per group. Data was expressed as mean \pm SE. $\mathrm{P}<0.05$.

- *Significantly different from the normal control value.

- a Significantly different from the vehicle control value.

- b Significantly different from silver nanoparticles value.

- c Significantly different from the irradiated control value.

Magnesium (Mg) content in various tissues of normal and irradiated (4Gy) rats treated with AgNPs:

Treatment with AgNPs $(26.878 \mathrm{mg} / \mathrm{kg})$ produced significant increase in $\mathrm{Mg}$ content in kidney as compared to vehicle and normal control groups. Irradiation (4Gy) significantly increased liver and testes $\mathrm{Mg}$ contents as compared to vehicle and normal control groups. It also significantly increased $\mathrm{Mg}$ content in kidney as compared to normal control group. Irradiation caused significant decrease in lung $\mathrm{Mg}$ content as compared to both vehicle and control groups. Although vehicle (PVP), AgNPs and 
irradiation exposure increased $\mathrm{Mg}$ content in kidney as compared to normal control, combined treatment of irradiation and AgNPs restored its value to the control level. Combined treatment with irradiation (4Gy) and AgNPs (42.599 mg/kg) significantly
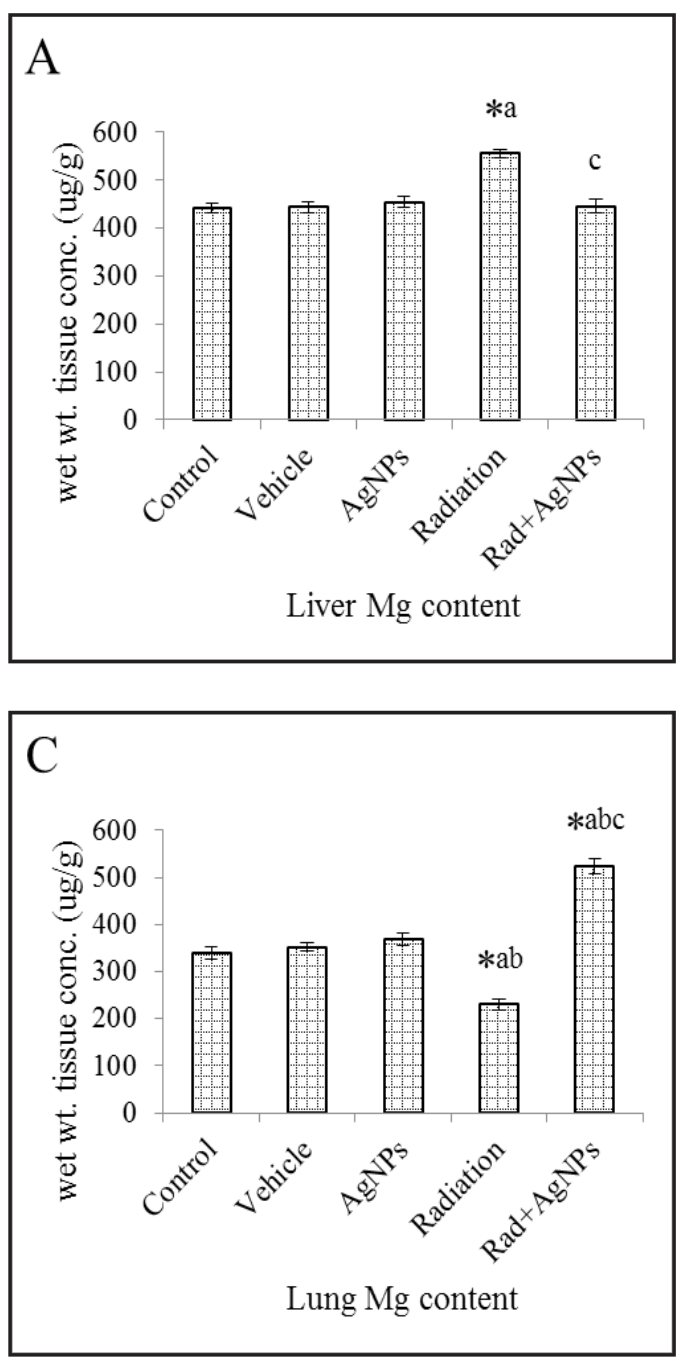

increased $\mathrm{Mg}$ content in lung as compared to all groups. AgNPs antagonize irradiation effect on liver and testes. Irradiation and AgNPs have a synergestic effect on lung Mg content. (Fig.9 A, B, C\&D).
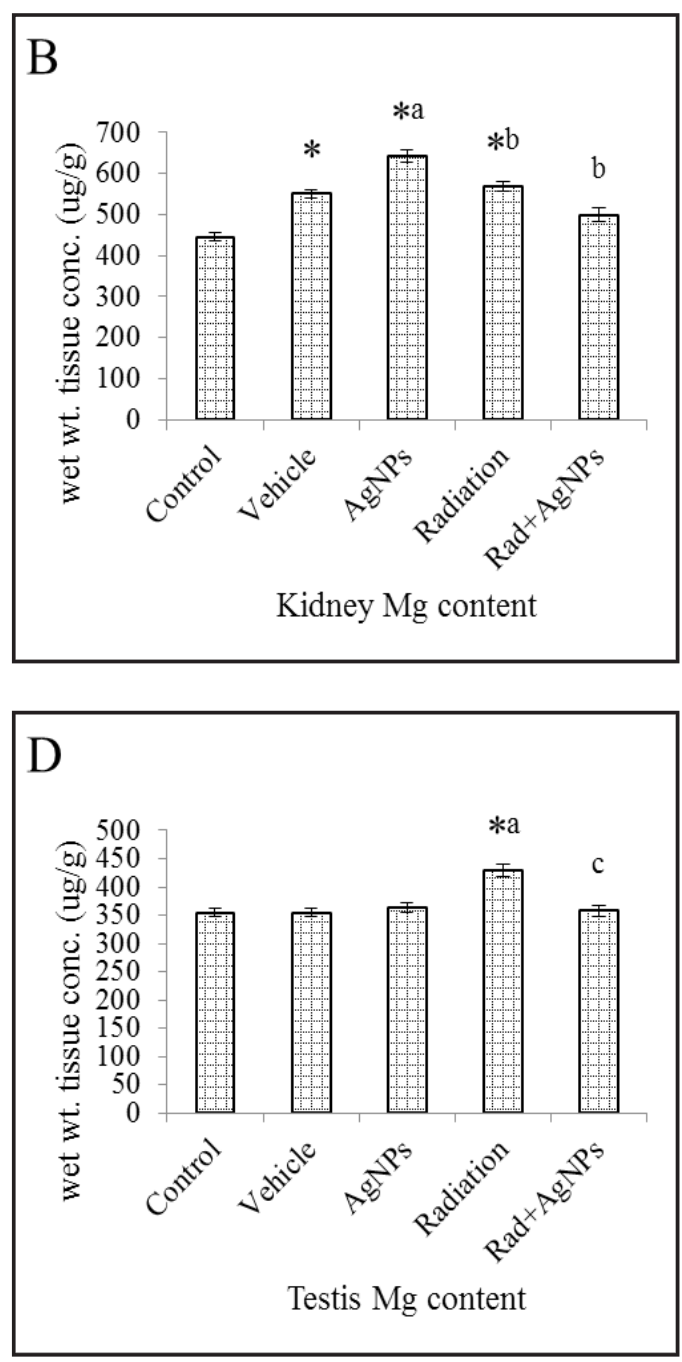

Fig. (9): shows subchronic effect of oral administration of AgNPs for 28 days in normal and irradiated (4Gy) rats on magnesium (Mg) contents in liver (A), kidney (B), lung (C) and testis (D) tissues.

- $\mathrm{n}=8$ rats per group. Data was expressed as mean $\pm \mathrm{SE}$. $\mathrm{P}<0.05$.

- *Significantly different from the normal control value.

- a Significantly different from the vehicle control value.

- b Significantly different from silver nanoparticles value.

- c Significantly different from the irradiated control value. 
Manganese (Mn) content in various tissues of normal and irradiated (4Gy) rats treated with AgNPs:

Treatment with AgNPs $(26.878 \mathrm{mg} / \mathrm{kg})$ showed a significant decrease in Mn content in lung as compared to vehicle control. Irradiation (4Gy) significantly increased testes $\mathrm{Mn}$ content as compared to vehicle control, normal control and AgNPs (26.878 $\mathrm{mg} / \mathrm{kg}$ ). Irradiation significantly increased lung $\mathrm{Mn}$ content as compared to normal control. Vehicle treatment increased Mn lung content. AgNPs administration decreased Mn content in lung as compared to
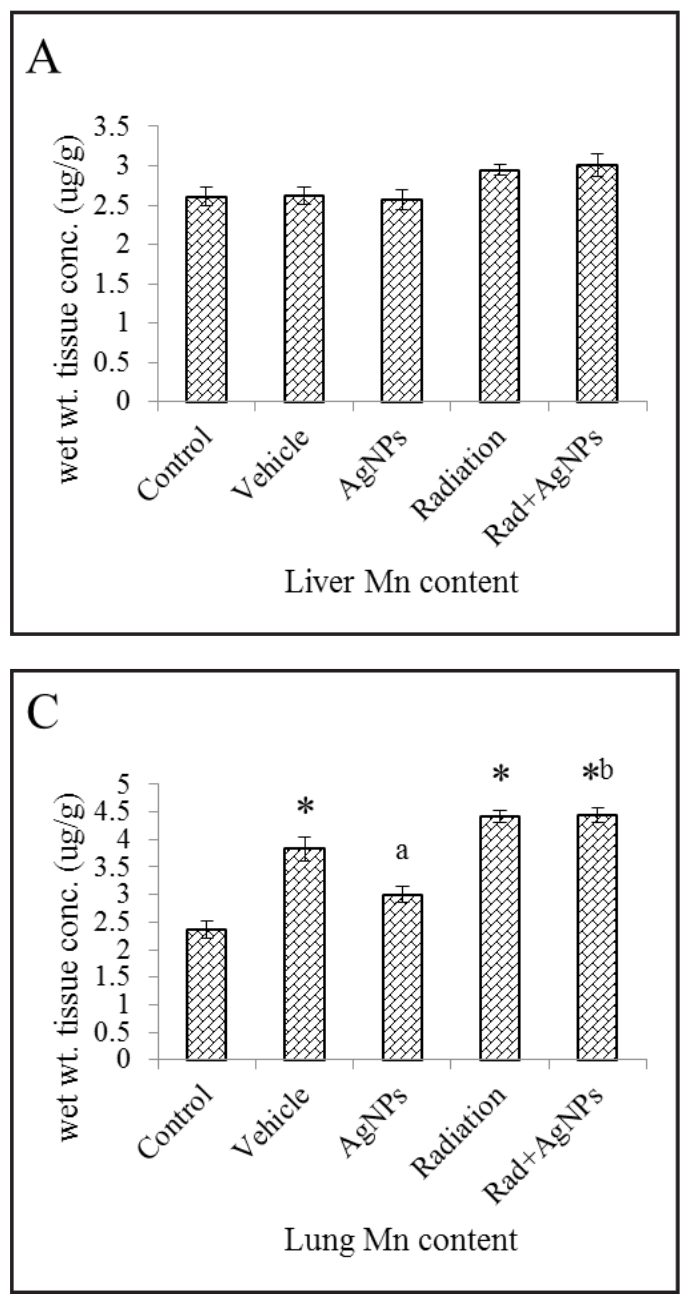

vehicle control. Irradiation increased $\mathrm{Mn}$ content in testes as compared to vehicle and normal controls. Combined treatment with irradiation (4Gy) and silver nanoparticles $(42.599 \mathrm{mg} / \mathrm{kg})$ significantly increased Mn content in lung as compared to normal control. Testes Mn content in the irradiated treated group showed significant increase as compared to vehicle control and normal control. Irradiation antagonized the effect of AgNPs effect on Mn content in lung whereas, AgNPs attenuate irradiation effect on Mn content in testes. (Fig.10 A, B, C\&D).
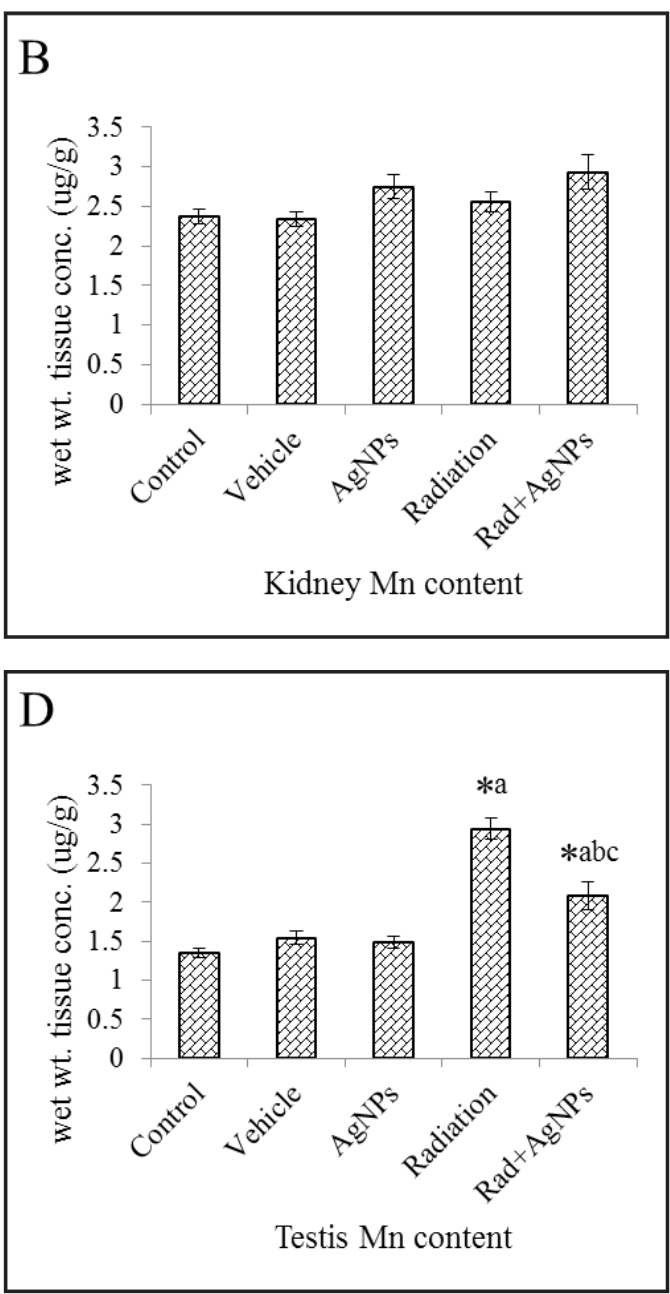

Fig. (10): shows subchronic effect of oral administration of AgNPs for 28 days in normal and irradiated (4Gy) rats on manganese (Mn) contents in liver (A), kidney (B), lung (C) and testis (D) tissues.

- $\mathrm{n}=8$ rats per group. Data was expressed as mean \pm SE. $\mathrm{P}<0.05$.

- *Significantly different from the normal control value.

- a Significantly different from the vehicle control value.

- b Significantly different from silver nanoparticles value.

- c Significantly different from the irradiated control value. 


\section{Discussion}

In the present study, trace elements $\mathrm{Fe}, \mathrm{Cu}, \mathrm{Zn}$, $\mathrm{Mg}, \mathrm{Ca}$ and $\mathrm{Mn}$ as well as $\mathrm{Ag}$ were estimated in the examined four organs (liver, kidney, lung and testes) of rats after 28 days subchronic oral administration of AgNPs to normal and to irradiated rats (4 Gy) at a dose level of $26.878 \mathrm{mg} / \mathrm{kg}$ and $42.599 \mathrm{mg} / \mathrm{kg}$ respectively (Amin et al., 2015). Results of the present study indicated that, accumulation of $\mathrm{Ag}$ due to oral administration of AgNPs $(26.878 \mathrm{mg} / \mathrm{kg})$ in the studied organs is in the ascending order of lung $>$ liver $>$ kidney>testes. Whereas, rats treated with AgNPs $(42.599 \mathrm{mg} / \mathrm{kg}$ ) after exposure to $\gamma$-irradiation (4Gy) led to different rank as kidney $>$ testes $>$ lung $>$ liver. According to Gmoshinski et al. (2016), oral treatment of rats with AgNPs resulted in a dose-dependent $\mathrm{Ag}$ accumulation in liver tissue at a dose of $0.1-10 \mathrm{mg} / \mathrm{kg}$ whereas in kidney tissue at a dose of $0.1-1 \mathrm{mg} / \mathrm{kg}$. Data of the present study revealed that, orally administration of AgNPs showed significant increase of $\mathrm{Zn}, \mathrm{Cu}$ and $\mathrm{Fe}$ contents in lung tissue as compared to untreated control rats whereas AgNPs administration after $\gamma$-radiation led to significant increase in liver and lung $\mathrm{Zn}, \mathrm{Cu}, \mathrm{Fe}$. The uptake of NPs occurs by the mononuclear phagocyte system (MPS) (Van Furth et al., 1972). The MPS comprises phagocytic cells, which are located in reticular connective tissue, as Kupffer cells in liver, alveolar and splenic macrophages. MPS has an important role in defense against bacteria, mycobacteria, viruses, protozoa, and fungi, also macrophages remove senescent erythrocytes, leukocytes, and megakaryocytes by phagocytosis and digestion (Das et al., 2015), also MPS can store Fe in liver, which resulted from heme catabolism after the breakdown of red blood cells (Hull et al., 2014). AgNPs uptakes depend on NPs ability to cross the capillary wall of the organs and phagocytosed in MPS (Brandenberger et al., 2010). It was recorded that the uptake/accumulation of AgNPs by the MPS increases with its higher concentration in the blood (Kim et al., 2008). Our data further indicated that, accumulation of $\mathrm{Ag}$ in kidney and testis tissues accompanied with elevation of $\mathrm{Zn}$ and Fe levels due to combined exposure with $\gamma$-radiation and AgNPs. It is not completely clear that the dissolved AgNPs interact with cell components, although it is suspected that AgNPs has physicochemical properties lead to unknown adverse health effects (Chen and Schluesener, 2008), such as the "Trojan Horse" effect (Kreuter, 2004). In "Trojanhorse" mechanism, NPs are internalized within cells and then release many of toxic ions (Hsiao et al., 2015). On the other hand, AgNPs may cause adverse effects by the generation of reactive oxygen species (ROS) and through the interaction with the thiol groups of proteins (Chen and Schluesener, 2008). In a study on the metabolism of AgNPs, detect that accumulation of NPs in the organs of rats exposed to NPs consist of sulfur and selenium (Kim et al., 2008 and Loeschner et al., 2011).

Results of the present study revealed that irradiation (4Gy) significantly increased $\mathrm{Zn}$ and Fe content in liver, lung and testes tissues as compared to normal control. These results are in agreement with previous investigators Beregovskaia et al., (1988), Nada et al., (2008) and Ashry et al. (2010) who found that whole body $\gamma$-irradiation induced an elevation of $\mathrm{Zn}$ in different organs. The increase of Fe level may be due to oxidative stress inducing proteolytic modification of ferritin and transferrtin Garcia-Fernander et al. (2005). In addition Nada et al., (2008) reported an increase of $\mathrm{Fe}$ content in liver after whole body irradiation. In the study of Crowe and Morgan (1996), $\mathrm{Fe}$ is required in oxidative metabolism to DNA synthesis and cell division. For resisting cell damage and inflammation, liver cells deliver more $\mathrm{Zn}$ to synthesize nucleic acids, proteins and enzymes related to zinc (Shiraishi et al., 1986). Combination treatment with irradiation (4Gy) and AgNPs $(42.599 \mathrm{mg} / \mathrm{kg})$ in the present study significantly increased $\mathrm{Zn}$ content in liver, kidney and testes tissues as compared to vehicle control, where significantly increased Fe content in liver and testes as compared to both vehicle control and normal control. Thus, ir- 
radiation and combined exposure of irradiation with AgNPs treatment led to accumulation of $\mathrm{Zn}$ and Fe in liver and lung organs. AgNPs potentiated the effect of irradiation on liver and kidney tissue content of trace elements. $\mathrm{Zn}$ is known as a free radical scavenger which affects the body's immune system through its essential role in the synthesis of nucleic acid as well as protein. The antioxidant role of $\mathrm{Zn}$ could be related to its ability to induce metalothioneins (Winum et al., 2007). There is increasing evidence that metalothioneins can reduce several types of free radical including superoxides, hydroxyl and peroxyl radicals (Pierrel et al., 2007). On the other hand, the present data revealed that AgNPs attenuated the effect of irradiation on testes. The redistribution of $\mathrm{Zn}$ after irradiation may be a biological protection behavior against irradiation Sorenson, (2002); these may include DNA repair, protein synthesis and scavenging the toxic free radicals. As essential metal, $\mathrm{Zn}$ is required for many cellular functions (Micheletti $\boldsymbol{e t}$ al., 2001). Also $\mathrm{Zn}$ protects various membrane systems from peroxidation damages induced by irradiation (Shiraishi et al., 1983; Matsubara et al., 1987) and stabilizes the membrane perturbation (Markant and Pallauf 1996 and Morcillo et al., 2000). Combined treatment with AgNPs and irradiation has synergistic effect on liver and kidney tissues content of the tested trace elements. AgNPs attenuated the effect of irradiation on testes tissues $\mathrm{Zn}$ content while irradiation antagonized AgNPs effect on lung tissue $\mathrm{Zn}$ content. Moreover, the high accumulation of Fe in liver due to radiation is closely correlated with the inhibition of ceruloplasmin which is essential for Fe metabolism and distribution (Osman et al., 2003 and Harris, 1995). The loss of feroxidase activity of ceruloplasmin resulted in systemic Fe deposition and tissue damage (Okamoto et al., 1996). According to Underwood, (1977), there is inverse correlation between hepatic $\mathrm{Fe}$ and $\mathrm{Cu}$ concentration in rats. $\mathrm{Fe}$ is an essential trace element that is vital for the function of Fe dependent enzymes as peroxidases, ribonucleuotide reductase, catalase and cytochrome.
$\mathrm{Fe}$ is also necessary for the function of hemoglobin. It is also associated with $\mathrm{Cu}$ in several functions as it is involved in the constituent of other oxidative system for amino acid. According to Papanikolaou and Pantopoulos (2005) $\mathrm{Fe}$ homeostasis has to be tightly controlled. Free Fe has been catalyzing the generation of ROS which attack and damage cellular macromolecules and promote tissue injury and cell death. The present study indicated that $\mathrm{Cu}$ content of testes and liver tissue, in the irradiated group showed significant increase compared to normal control, where whole body $\mathrm{X}$-ray irradiation increased $\mathrm{Cu}$ concentration Tamanoi et al. (1995).

In the study of AshaRani et al. (2009), cells treated with AgNPs for 4 hours showed a drop in $\mathrm{Ca}^{2+}$ concentration, as well as Moutin et al. (1989) provided evidence that $\mathrm{Ag}^{+}$ions act on the same site as $\mathrm{Ca}^{2+}$ ions, regulating the release of $\mathrm{Ca}^{2+}$ from sarcoplasmic reticulum. On the other hand Orrenius et al., (1992) showed that higher concentration of $\mathrm{Ag}^{+}$ion inhibited $\mathrm{Ca}^{2+}$ release from the intracellular stores. AgNPs could release $\mathrm{Ag}^{+}$ions through surface oxidation which lead to fluctuations of $\mathrm{Ca}^{2+}$ in a similar way AshaRani et al. (2009); it may explain the increase of $\mathrm{Ca}$ content in kidney tissue of irradiated rats. Disruption of calcium homeostasis is an early sign of cell injury which plays a major role in pathological and toxicological conditions. Repeated calcium influx and efflux in mitochondria could result in mitochondrial membrane damage, resulting in ROS production and inhibition of ATP synthesis Orrenius et al. (1992). Whole body $\gamma$-radiation exposure caused disturbance and alteration of $\mathrm{Ca}$ level in the blood Fauxcheux et al., (1976). El Nimr and Abdel-Rahim (1998) found that exposure of rats to $\gamma$-radiation (5Gy) increase levels of $\mathrm{Ca}$ in lung, liver and kidney tissues. The disturbances of calcium metabolism after irradiation may be attributed to the insufficient renal function Kotb et al. (1990). On the other hand, results of the present study revealed that AgNPs $(26.878 \mathrm{mg} / \mathrm{kg})$, irradiated and irradiated rats treated with AgNPs (42.599 mg/kg) showed 
increased $\mathrm{Ca}$ content in kidney tissue as compared to normal control. The increase of $\mathrm{Ca}$ content may be attributed to hypoxia induced by oxidative stress this explanation is in accordance with the results of Berna et al. (2001).

Irradiation (4Gy) significantly increased $\mathrm{Mg}$ content in liver, kidney and testes tissue as compared to normal control. Irradiation caused significant decrease in lung tissue $\mathrm{Mg}$ content as compared to both vehicle and control groups. The present results are in accordance with the results Yukawa et al. (1980) and Symthe et al. (1982). Combination of irradiation (4Gy) and AgNPs (42.599 mg/kg) significantly increased $\mathrm{Mg}$ content in lung tissue as compared to vehicle control and normal control. AgNPs antagonized irradiation effect on liver, kidney and testes. Irradiation and AgNPs have synergestic effect on lung $\mathrm{Mg}$ content. Furthermore, Nada et al. (2008) reported that the redistribution of $\mathrm{Ca}$ and $\mathrm{Mg}$ in tissue organ may respond in recovery from radiation-induced pathology or in repairable damage in biomemebrane and to prevent irreversible cell damage.

Results of the present study demonstrated that $\mathrm{Mn}$ and $\mathrm{Fe}$ content in lung and testes tissues increased in irradiated and the irradiated group treated with AgNPs. Fe and Mn can share common absorption and transport pathways Fitsanakis et al. (2010). Liver content of Mn in AgNPs, irradiated (4Gy) and irradiated treated group with AgNPs did not change. $\mathrm{Mn}$ is eliminated from the body mainly in the bile, thus the impaired liver function may lead to decreased Mn secretion Keen et al. (1999). However irradiation induced decrease of $\mathrm{Mn}$ in liver and other organ tissues Nada and Azab (2005).

In conclusion, radiation damage to living biological tissues is associated with membrane permeability which accompanied with corresponding alterations in the essential trace element content of $\mathrm{Zn}, \mathrm{Cu}$, $\mathrm{Fe}, \mathrm{Ca}, \mathrm{Mg}$, and $\mathrm{Mn}$ in the various examined organs tissue, liver, kidney, lung and testes. Subchronic oral administration of AgNPs induced marked changes in the concentration of the estimated essential elements in the various examined organs tissue of normal rats. Combined treatment with irradiation and AgNPs showed alterations in the elements content of the various organs tissue investigated. The demonstrated variation of the essential elements in the various organs examined might be attributed to the selective responsiveness of each tissue to the AgNPs and/or $\gamma$-irradiation treatments. AgNPs administration to normal rats or $\gamma$-irradiated rats has considerate effect on the levels of trace elements especially $\mathrm{Zn}, \mathrm{Cu}$ and $\mathrm{Fe}$ in liver and lung tissues which give attention that these organs more sensitive to AgNPs.

Additional studies however, several studies are needed to gain further insight into the underlying mechanisms of the observed disturbances of essential trace element contents in the various examined organs (liver, kidney, lung, testes) in response to AgNPs treatment in normal and irradiated rats.

\section{ACKNOWLEDGEMENT}

This study was performed in the National Center for Radiation Research and Technology (NCRRT), Atomic Energy Authority, Cairo, Egypt. We are grateful to Professor Dr. Ahmed Shafik Nada, Prof. of physiology, Drug Radiation Research Department, NCRRT for offering all facilities to measure the trace elements in Atomic Absorption Spectrometry lab. Also the authors are appreciating to the staff members of gamma irradiation unit of NCRRT for carrying out the irradiation process of experiment.

\section{REFERENCES}

- Amin,Y.M.; Hawas, A.M.; El-Batal, A.I.; Hassan, S.H.M. and Elsayed, M.E. (2015): Evaluation of acute and subchronic toxicity of Silver nanoparticles in normal and irradiated animals. BJPT, 6(2): 22.

- AshaRani, P.V.; Hande, M.P. and Valiyaveettil, S. (2009): Anti-proliferative activity of silver nanoparticles. BMC Cell Biology, 10:65. 
- Ashry, O.M.; Kafafy, Y.A. and El-Tawil, G.A. (2010): Influence of hesperidin on lipid metabolism, oxidative stress and related trace elements in $\gamma$-irradiated rats. Egypt. J. Rad. Sci. Applic., 23(1): 15.

- Benetti, F.; Bregoli, L.; Olivato, I. and Sabbioni E. (2014): Effects of metal(loid)-based nanomaterials on essential element homeostasis: the central role of nanometallomics for nanotoxicology. Metallomics., 6(4): 729.

- Beregovskaia, N.N.; Sidorik, E.P.; Udovichenko, T.V. and Chebotarev, E.E. (1988): The state of the molecular electron carriers of the cell energy system at early periods following irradiation. Radiobiologiia., 28(5): 588.

- Berna, N.; Arnould, T.; Remacle, J. and Michiels, C. (2001): Hypoxia-induced increase in intracellular calcium concentration in endothelial cells: role of the $\mathrm{Na}(+)$-glucose cotransporter. J. Cell. Biochem., 84(1): 115 .

- Brandenberger, C.; Mühlfeld, C.; Ali, Z.; Lenz, A.G.; Schmid, O.; Parak, W.J.; Gehr, P. and Rothen-Rutishauser, B. (2010): Quantitative evaluation of cellular uptake and trafficking of plain and polyethylene glycol-coated gold nanoparticles. Small, 6(15): 1669.

- Chen, X. and Schluesener, H.J. (2008): Nanosilver: a nanoproduct in medical application. Toxicol. Lett., 176(1): 1.

- Choi, O.; Deng, K.K.; Kim, N.J.; Ross Jr., L.; Surampalli, R.Y. and Hu, Z. (2008): The inhibitory effects of silver nanoparticles, silver ions, and silver chloride colloids on microbial growth. Water Res.. 42(12): 3066.

- Christensen, F.M.; Johnston, H.J.; Stone, V.; Aitken, R.J.; Hankin, S.; Peters, S. and Aschberger, K. (2010): Nano-silver - feasibility and challenges for human health risk assessment based on open literature. Nanotoxicology, 4(3): 284.

- Crowe, A. and Morgan, E.H. (1996): Iron and copper interact during their uptake and deposition in the brain and other organs of developing rats exposed to dietary excess of the two metals. J. Nutr., 126: 183 .

- Das, A.; Sinha, M.; Datta, S.; Abas, M.; Chaffee, S.; Sen, C.K. and Roy, S. (2015): Monocyte and macrophage plasticity in tissue repair and regeneration. Am. J. Pathol., 185(10): 2596.

- De, M.; Ghosh, P.S. and Rotello, V.M. (2008): Applications of nanoparticles in biology. Adv. Mater. 20(22): 4225 .

- El-Batal, A.I.; Amin, M.A.; Shehata, M.M.K. and Hallol, M.M.A. (2013a): Synthesis of silver nanoparticles by bacillus stearothermophilus using gamma radiation and their antimicrobial activity. World Appl. Sci. J., 22(1):1.

- El-Batal, A.I.; El-Baz, A.F.; Abo Mosalam, F.M. and Tayel, A.A. (2013b): Gamma irradiation induced silver nanoparticles synthesis by Monascus purpureus. J. Chem. Pharm. Res., 5(8): 1.

- El-Nimr, T. and Abdel-Rahim, S.M. (1998): Effect of gamma radiation on some elements in certain organs of albino rats. Biol. Trace Elem. Res., 68(1-2): 25 .

- Fauxcheux, B.; Kuchel, O.; Cuche, J.L.; Messerli, F.H.; Buu, N.T.; Barbeau, A. and Genest, J. (1976): Circadian variations of the urinary excretion of catecholamines and electrolytes. Endocr. Res. Commun., 3(5): 257.

- Fitsanakis, V.A.; Zhang, N.; Garcia, S. and Aschner, M. (2010): Manganese (Mn) and iron (Fe): interdependency of transport and regulation. Neurotox. Res., 18(2): 124.

- Garcia-Fernandez, M.; Castilla-Cortazar, I.; DiazSanchez, M.; Navarro, I.; Puche, J.E.; Castilla, A.; Casares, A.D.; Clavijo, E. and González-Barón, S. (2005): Antioxidant effects of insulin-like growth factor-1(GF-1) in rats with advances liver cirrhosis. BMC Gastroenterol., 5(7): 1.

- Ghosh Chaudhuri, R. and Paria, S. (2012): Core/ shell nanoparticles: Classes, properties, synthesis Mechanisms, characterization, and applications. Chem Rev., 112(4): 2373. 
- Gmoshinski, I.V.; Shumakova, A.A.; Shipelin, V.A.; Maltsev, G.Yu. and Khotimchenko, S.A. (2016): Influence of orally introduced silver nanoparticles on content of essential and toxic trace elements in organism. Nanotechnologies in Russia, 11(9-10): 646.

- Harris, E.D. (1995): The iron-copper connection: the link to ceruloplasmin grows stronger. Nutr Rev., 53(6): 170 .

- Hassan, S.; El-Sayed, N.M.; Hussein, A.H. and Anis, L.M. (2005): Disturbance in certain essential elements concentrations in various tissues of mice by exposure to gamma radiation and/or magnetic field. Isotope \& Rad. Res., 37(6): 1658.

- Hawas, A.M. (2013): Effect of low dose gamma rays on certain essential metals and oxidative stress in different rat organs. J. Rad. Res. Appl. Sci., 6(2): 1

- Hsiao, I.L.; Hsieh, Y.K.; Wang, C.F.; Chen, I.C. and Huang, Y.J. (2015): Trojan-horse mechanism in the cellular uptake of silver nanoparticles verified by direct intra- and extracellular silver speciation analysis. Environ. Sci. Technol., 49(6): 3813.

- Hull, T.D.; Agarwal, A. and George, J.F. (2014): The mononuclear phagocyte system in homeostasis and disease: a role for heme oxygenase-1. Antioxid. Redox Signal., 20(11): 1770.

- IAEA. (1980): Elemental analysis of biological materials; international Atomic Energy Agency. IAEA, No 197, 379. Veinna Technical report series.

- Keen, C.L.; Ensunsa, J.L.; Watson, M.H.; Baly, D.L.; Donovan, S.M.; Monaco, M.H. and Clegg, M.S. (1999): Nutritional aspects of manganese for experimental studies. Neurotoxicology, 20(2-3): 213.

- Kim, Y.S.; Kim, J.S.; Cho, H.S.; Rha, D.S.; Kim, J.M.; Park, J.D.; Choi, B.S.; Lim, R.; Chang, H.K.; Chung, Y.H.; Kwon, I.H.; Jeong, J.; Han, B.S. and Yu, I.J. (2008): Twenty-eight-day oral toxicity, genotoxicity, and gender-related tissue distribution of silver nanoparticles in Sprague-Dawley rats. Inhal. Toxicol., 20(6): 575.
- Kingston, H.M. and Jassei, L.B. (1988): Introduction to microwave sample preparation. ACS, Washington: DC, p 126.

- Kotb, M.A.; El-khatib, A.M.; Morsey, A.A.; Ramadan, M.I.A. and El-Bassiouni, E.A. (1990): Changes in mineral elements in some tissues of mice following neutron irradiation. Isotop-enpaxis., 26(7): 297.

- Kreuter, J. (2004): Influence of the surface properties on nanoparticle-mediated transport of drugs to the brain. J. Nanosci. Nanotechnol., 4(5): 484.

- $\quad$ Loeschner, K.; Hadrup, N.; Qvortrup, K.; Larsen, A.; Gao, X.; Vogel, U.; Mortensen, A.; Lam, H.R. and Larsen, E.H. (2011): Distribution of silver in rats following 28 days of repeated oral exposure to silver nanoparticles or silver acetate. Part. Fibre. Toxicol., 8: 18.

- $\quad$ Lu, L.; Sun, R.W.; Chen, R.; Hui, C.K.; Ho, C.M.; Luk, J.M.; Lau, G.K. and Che, C.M. (2008): Silver nanoparticles inhibit hepatitis B virus replication. Antivir. Ther., 13(2): 253.

- Lubick, N. (2008): Nanosilver toxicity: ions, nanoparticles--or both?. Environ. Sci. Technol., 42(23): 8617.

- Mao, A.; Jin, X.; Gu, X.; Wei, X. and Yong, G. (2012): Rapid green synthesis and surface enhanced Raman scattering effect of single crystal silver nanocupes. J. Mol. Struc., 1021: 158.

- Marambio-Jones, C. and Hoek, E.M. (2010): A review of the antibacterial effects of silver nanomaterials and potential implications for human health and the environment. J. Nanopart. Res., 12: 1531.

- Markant, A. and Pallauf, J. (1996): Metallothionein and zinc as potential antioxidants in radical-induced lipid peroxidation in cultured hepatocytes. J. Trace Elem. Med. Biol., 10(2): 88

- Matsubara, J.; Tajima, Y. and Karasawa, M. (1987): Metallothionein Induction as a Potent Means of Radiation Protection in Mice. Radiat. Res., 111(2): 267. 
- $\quad$ Micheletti, A.; Rossi, R. and Rufini, S. (2001): Zinc status in athletes: relation to diet and exercise. Sports Med., 31(8): 577.

- Morcillo, M.A.; Rucandio, M.I. and Snatamaría, J. (2000): Effect of gamma radiation on liver metallothionein synthesis and lipid peroxidation in rats. Cell. Mol. Biol., 46(2): 435.

- Morones, J.R.; Elechiguerra, J.L.; Camacho, A.; Holt, K.; Kouri, J.B.; Ramírez, J.T. and Yacaman; M.J. (2005): The bactericidal effect of silver nanoparticles. Nanotechnology, 16(10): 2346.

- Moutin, M.J.; Abramson, J.J.; Salama, G. and Dupont, Y. (1989): Rapid Ag+-induced release of Ca2+ from sarcoplasmic reticulum vesicles of skeletal muscle: a rapid filtration study. Biochim. Biophys. Acta, 984: 289.

- Nada, A.S. and Azab, K. (2005): Induction of cellular metallothionein in irradiated rats supplemented with Egyptian proplis extract. Egypt. J. Rad. Sci. Applic., 18(2): 351.

- Nada, A.H.; Gharib, O.A.; Noaman, E. and Amin, N.E. (2008): Early sings of trace element alterations induced by environmental pollutants and radiation exposure in rats. Egypt. J. Rad. Sci. Applic., 21(2): 515.

- Okamoto, N.; Wada, S.; Oga, T.; Kawabata, Y.; Baba, Y.; Habu, D.; Takada, Z. and Wada, Y. (1996): Hereditary ceruloplasmin deficiency with hemosiderosis. Hum. Genet., 97(6): 755.

- Orrenius, S.; McCabe Jr., M.J. and Nicotera, P. (1992): $\mathrm{Ca}(2+)$-dependent mechanisms of cytotoxicity and programmed cell death. Toxicol. Lett., 64-65:357.

- Osman, S.A.; Abu Ghadeer, A.R.; Yousri, R.M.; Abdallah, N.M. and El-Fatih, N.M. (2003): Protective role of 6,8-thioctic acid against metalloproteins impairment induced by gamma irradiation in rats. Egypt. J. Rad. Sci. Applic., 16(1): 27.

- Papanikolaou, G. and Pantopoulos, K. (2005): Iron metabolism and toxicity. Toxicol. Appl. Pharmacol., 202(2): 199 .
- $\quad$ Pierrel, F.; Cobine, P.A. and Winge, D.R. (2007): Metal ion availability in mitochondria. Biometals., 20(3-4): 657 .

- $\quad$ Roe, D.; Karandikar, B.; Bonn-Savage, N.; Gibbins, B. and Roullet, J.B. (2008): Antimicrobial surface functionalization of plastic catheters by silver nanoparticles. J. Antimicrob. Chemother, 61(4): 869.

- Sharma, V.K.; Yngard, R.A. and Lin, Y. (2009): Silver nanoparticles: green synthesis and their antimicrobial activities. Adv. Colloid. Interface Sci., 145(1-2): 83 .

- Shazia, Q.; Mohammad, Z.H.; Rahman, T. and Shekhar, H.U. (2012): Correlation of oxidative stress with serum trace element levels and antioxidant enzyme status in beta thalassemia major patients: a review of the literature. Anemia., 2012: 1.

- Shiraishi, N.; Aono, K. and Utsumi, K. (1983): Increased metallothionein content in rat liver induced by $\mathrm{X}$ irradiation and exposure to high oxygen tension. Radiat. Res., 95(2): 298.

- Shiraishi, N.; Yamamoto, H.; Takeda, Y.; Kondoh, S.; Hayashi, H.; Hashimoto, K. and Aono, K. (1986): Increased metallothionein content in rat liver and kidney following X-irradiation. Toxicol. Appl. Pharmacol., 85(2): 128.

- $\quad$ Sorenson, J.R. (2002): $\mathrm{Cu}, \mathrm{Fe}, \mathrm{Mn}, \mathrm{Zn}$ Chelates offer a medicinal chemistry approach to overcoming radiation injury. Curr. Med. Chem., 9(6): 639.

- Symthe, W.R.; Alfrey, A.C.; Crawell, P.W.; Crouch, C.A.; Ibels, L.S.; Kubo, H.; Nunnelley, L.L. and Rudolph, H. (1982): Trace element abnormalities uremia. Ann. Intern. Med., 96(3): 302.

- Tamanoi, I.; Nakamura, A.; Hashikawa, K.; Kachi, M.; Goto, B.; Joshima, H. and Matsumoto, S. (1995): Changes of blood plasma element contents in $\mathrm{X}$-rays irradiated mice by Pixe Analysis. Int. J. PIXE, 5: 85 .

- $\quad$ Tripathy, A.; Raichur, A.M.; Chandrasekaran, N.; Prathna, T.C. and Mukherjee, A. (2010): Process variables in biomimetic synthesis of silver nanoparti- 
cles by aqueous extract of Azadirachta indica (Neem) leaves. J. Nanoparticle Res., 12(1):237-246.

- Underwood, E.J. (1977): Trace Elements in Human and Animal Nutrition; $4^{\text {th }}$ Ed. New York, San Francisco and London: Academic Press Inc.

- Van Der Zande, M.; Vandebriel, R.J.; Van Doren, E.; Kramer, E.; Herrera Rivera, Z.; Serrano-Rojero, C.S.; Gremmer, E.R.; Mast, J.; Peters, R.J.; Hollman, P.C.; Hendriksen, P.J.; Marvin, H.J.; Peijnenburg, A.A. and Bouwmeester, H. (2012): Distribution, elimination, and toxicity of silver nanoparticles and silver ions in rats after 28-day oral exposure. ACS Nano., 6(8): 7427.

- Van Furth, R.; Cohn, Z.A.; Hirsch, J.G.; Humphrey, J.H.; Spector, W.G. and Langevoort HL. (1972): The mononuclear phagocyte system: a new classification of macrophages; monocytes; and their precursor cells. Bull. World Health Organ., 46(6): 845.
- Winum, J.Y.; Scozzfava, A.; Montero, J.L. and Supuran, C.T. (2007): Metal binding functions in design of carbonic anhydrase inhibitors. Curr. Top. Chem., 7(9): 835.

- Xiu, Z.M.; Zhang, Q.B.; Puppala, H.L.; Colvin, V.L. and Alvarez, P.J. (2012): Negligible particlespecific antibacterial activity of silver nanoparticles. Nano Lett., 12(8): 4271.

- Yukawa, M.; Amano, K.; Suzuk-Yosumot, M. and Terai, M. (1980): Distribution of trace elements in the human body determined by neutron activation analysis. Arch. Environ. Health, 35(1): 36. 